\title{
Anthós
}

\section{Knowledge is Power: The Political Influence of the Chanter Social Circle at the University of Paris (1200-1215)}

Andrew X. Fleming

Portland State University

Follow this and additional works at: https://pdxscholar.library.pdx.edu/anthos

Part of the European History Commons, History of Religion Commons, Intellectual History Commons, and the Medieval History Commons

Let us know how access to this document benefits you.

\section{Recommended Citation}

Fleming, Andrew X. (2015) "Knowledge is Power: The Political Influence of the Chanter Social Circle at the University of Paris (1200-1215)," Anthós: Vol. 7: Iss. 1, Article 3.

https://doi.org/10.15760/anthos.2015.3

This open access Article is distributed under the terms of the Creative Commons Attribution-NonCommercialShareAlike 4.0 International License (CC BY-NC-SA 4.0). All documents in PDXScholar should meet accessibility standards. If we can make this document more accessible to you, contact our team. 


\section{Knowledge is Power: The Political Influence of the Chanter Social Circle at the University of Paris (1200-1215)}

Andrew X. Fleming

At the onset of the bloody conflicts which came to be known as the Albigensian Crusades, a small group of theologians hailing from the University of Paris set in motion a series of events that dramatically altered the political realities of thirteenth century Europe. Through papal-mandated diplomacy and the scholarly construction of a refined understanding of heresy, the Parisian faculty of theology, following the teachings of Master Peter Cantor, laid the groundwork for a French invasion of Occitania. Without the aid of these theologians in manipulating the political and intellectual landscape, the papacy may never have united the French to their cause in exterminating the heresies of Occitania.

The faculty of theology within the medieval University of Paris formed a major node within the social network of thirteenth-century Europe. Through an analysis of papal and university statutes concerning the development of a defined understanding of heresy, an overview of the historiographic methodologies traditionally used in studying such a topic, and a prosopographically-based analysis of the actions taken by Pope Innocent III and a small circle of theologians at Paris, we will come to a more clarified understanding of the political motivations driving academic reform within the thirteenth century. More specifically, this study will examine precisely how the papacy worked to directly alter both the curriculum and the faculty makeup of the University of Paris, in order to utilize the department of theology there as a political platform for the pope's own cause: an effort to coerce the throne of France to go to war with the heretics of Occitania. 
Anthós, Vol. VII, Issue 1

\section{The Material Evidence}

The issue of what sources to use, or perhaps more accurately, of how to use them, must be at the forefront of such a study as this. For our purposes it is most beneficial to analyze the more sweeping and widely read decrees made by the papacy and theologians of Paris, in order to understand the real ways in which both parties were effectively seeking to alter the political realities of the day. To this end, our study will focus primarily upon the Third and Fourth Lateran Councils, which clarified the official understanding of what heresy was; the proclamations of Pope Innocent III in regards to heretical teachings at universities, and how such heresies were to be legally handled by ecclesiastical and secular authorities; the statutes issued to the University of Paris concerning the proper teaching of theology and philosophy, generally decreed by theologians holding ecclesiastic office; and lastly the Giessen Codex, an eyewitness account of the Fourth Lateran Council.

Largely held to codify canon law in regards to what constituted heresy, how to appropriately react to it, and how to properly punish heretics, the Third and Fourth Lateran Councils, held in 1179 and 1215 respectively, are indispensable to the study of the socio-political climate of the High Middle Ages. Being widely discussed amongst ecclesiastical and secular powers alike, the highly read records of the Lateran Councils provide some of the most culturally pervasive sources we have from the time, and for that reason are invaluable to our understanding of the broad political trends in Catholic Europe.

The Third Lateran Council, though it predates the main focus of this study, is nonetheless essential to building an informed understanding of both the political climate, and how it was affected by official definitions of heresy. Particularly because of the document's call for the anathematization of all those who were deemed to be heretics, and the promise of remissions of sins offered to those who killed heretics at the bequest of papal authority (Peters 169-170). Interestingly, despite this papal justification for holy wars on heretics, at the time of the Third Lateran Council the punishment of heresy was often one of attempted reconciliation with the church (165). Despite this fact, it was the Cathars, future targets of the Albigensian Crusades, who garnered the first universal 
anathematization which went on to become the excuse of their demise.

When the Fourth Lateran Council was called by Pope Innocent III, the Albigensian Crusades were well underway, and the notion of reconciliation had been long since left behind. This council is of central importance to the study of papal interference within academia and politics (the precise role of the Parisian theologians with the Council will be examined later in this paper). It officially codified the church under the pope's authority as being the sole source of salvation for all mankind (174). More importantly, it ruled that any secular authority could be admonished and censured by the church, and that any who were deemed heretical in their beliefs were to have their lands forfeited to any Catholic that was willing to take up arms against them (175). This last guarantor of land and wealth for those who heeded the call against heresy, proved an apt recruiting tool for the church in France, though one must wonder to what extent King Philip Augustus may have taken the decree of papal authority over all secular lordships as a potential threat to his dominion.

Another decretal of Innocent III, the Cum ex Officii Nostri, as well as a number of decrees at the University of Paris in 1210, 1212, and 1215, provide a firm basis for uncovering the actions and motives of the faculty of theology in conjunction with the pope himself. These include statutes which altered the core makeup of the university faculty and its curriculum at the behest of the pope. Though less widespread in their readership than the Councils, these charters offer a telling look into the political machinations of the papacy at the University of Paris, and were known well at the university and throughout upper church leadership.

Lastly, an eyewitness account of the Fourth Lateran Council, known now as the Giessen Codex, is of use to unveil the behind the scenes involvements of those who worked on creating the Council. Though simply a private letter with extraordinarily limited readership in its day, the Codex nonetheless provides an intriguing outside perspective to the ongoings of the political maneuverings of clerics, theologians, and lords alike at the Fourth Lateran Council. It is for these reasons the Giessen Codex is a perfect fit for contextualizing the circumstances under which the other documents were drafted. 
Anthós, Vol. VII, Issue 1

\section{The Historiographical Tradition}

The majority of analyses written over the last century concerning the faculty of theology at Paris during the beginning of the thirteenth century have generally been realized through one of two historiographical understandings of the era. The first tradition has focused upon a specifically intellectual history of the development of academic methodologies in the medieval era; and the second has espoused a critical understanding of how the church seemingly interfered with the more "scientific" pursuits at medieval universities.

In regards to the former, intellectually-centered studies, their use is unfortunately limited in regards to developing an understanding of the political contexts behind such developments outside of an academic vacuum. Perhaps this is due to the recent trends of disciplinary specialization, or also to the desire of many intellectual historians to focus purely on the methodological changes in science and academia apart from their political contexts. Whatever the reason, the scholarship utilized within this study will largely abstain from works which are singularly focused on what academic policies were, and will be more focused toward those histories which examine the socio-political cause for why academic policies were what they were.

As to the examinations in the historiographical tradition of church-university relations, while mostly useful for understanding just how individually driven some such relations were, such studies have largely tended (even in contemporary post-modernity) toward a teleological methodology. Often it is still not uncommon to find such theses widely promulgating an antiquated notion of the inevitable rise of modern science out of the murky depths of religious persecution. This is perhaps due, I hope, to a small drought of scholarship on the issue over the last four decades, and not to recent pedagogical desires to separate education from any semblance of religiosity. Additionally, newer scholarship that is pioneered with a well contextualized vision and care for the socio-political realities of the age have generally focused either on the development of heresy in its early forms, as seen in the impressive scholarship of Heinrich Fichtenau and Robert Moore; or on the more well documented institution of the inquisition and academic condemnations of 1277 and later, as seen in much of the writings of Ian Wei. These trends combined have, to some extent, cast a haze over our lenses when attempting to understand academia, 
heresy, and politics in the early thirteenth century, due to either dated methodological hue or lack of focus on the time-period within this context.

For our purposes then, a newer methodology must be implemented in an attempt to arrive at a more contextualized understanding of the role that the Parisian theologians played in the Albigensian Crusades. This method shall largely be focused upon developing a social history which is semi-prosopographically realized, in that it will be focused largely upon an examination of the political careers of the Parisian faculty of theology as a social unit. Viewing the actions of this group as a whole, while keeping in mind both Kuhn and Moore's insistence of realizing individual human actors, and not institutional abstractions, as being the creators of history, will help to craft an image of the medieval university which is more appropriately realized within its socio-cultural and political contexts, which will allow us to view the Cantor circle at Paris, and theologians of the Middle Ages at large, not as some scholars have simply said, in dealing with academic and "purely dialectical premiums" (Leff 181). Rather, this study aims to prove the academic elite as being an exclusive social group who dealt daily in both political affairs and ideas which held quite tangible consequences for Christendom as a whole.

\section{Academia, Condemnation, and Politics at the University of Paris}

The influence of the University of Paris upon the politics and religion of Medieval Europe cannot be overstated. Historian Gordon Leff said of the situation that whatever happened at the university had "European-wide ramifications," and that the faculty of theology in particular were indeed "the doctrinal and intellectual nerve center of Christendom" (187 and 164). Put simply, the university's authority over all issues moral and academic in nature was not a disputed point (Wei 169). The discipline of theology and the pursuit of its political applications at the onset of the Albigensian Crusades saw the field continue soaring to new heights of importance concerning official dogma, until its shadow grew to encompass the understanding of all other academic fields as well. Eventually the theologian was catapulted into the esteemed role of the universal expert (McLaughlin 171). So distinguished was the faculty of theology at Paris, that its 
authority extended to the near-exclusive right to arbitrate matters of ecclesiastical doctrine, papal authority, and the suppression or authentication of suspect and erroneous philosophical works (239 and 282). It is through this unparalleled influence on intellectual thought in the Middle Ages that the University of Paris exercised its influence over the culture and politics of Europe, becoming what has been called a "state within a state," and its theologians garnering the title of the vox populi of the thirteenth century (Scott 79, 100, and 102).

Academic methodologies no doubt played a great role in developing the various doctrines of Christendom, whose creation was largely accorded to the purview of the Parisian theologians. The medieval masters were renowned to some extent for logically analyzing and publically debating for and against various interpretations of doctrinal beliefs in a classically pro et contra style. ${ }^{1}$ These debates were closely tied to the political events of the day and primarily concerned the appropriate interpretation of scripture, and thus also the defining of heresy. Paris, after all, had become the economic hub of France by the onset of the thirteenth century, and the university was the cosmopolitan nucleus of Paris. The love for scholarly discourse reflected this. However, for Pope Innocent III, this cosmopolitan appreciation for open, diverse, and at times quite lively discourse, reflected far too well the immense value of religious and intellectual debate held in the Occitanian south. In the decentralized and urban atmosphere of Occitania, Cathars and Catholics predominantly lived side by side, and heretics could freely discuss their views as equals with the church's representatives. The papacy needed a way to expunge the undesirable elements that such a system of open discourse invariably produced, and sought to regain a cultural control over Occitania. ${ }^{2}$

The pope, growing ever-weary of the increasingly non-traditional interpretations of canon held by laymen and lord alike, and becoming

\footnotetext{
${ }^{1}$ For insights to the processes of scholarly debate, see: Scott, Influence of the Medieval University 96-97 and McLaughlin, Intellectual Freedom 181. For an overview of the quodlibeta, or "free discussions," see: Leff, Paris and Oxford 163.

${ }^{2}$ For notes on the role of cosmopolitanism in the Albigensian Crusades, see: Strayer, Albigensian Crusades 8. For cathar-catholic interactions in Occitania see: Strayer, Albigensian Crusades 22-23 and 42.
} 
consistently more annoyed with King Philip of France's uncompromising refusals to join in a crusade to Occitania, received the chance he had been waiting for in 1208. While on a preaching mission in heretic controlled Languedoc, a papal legate named Pierre de Castelnau was assassinated. His murder was quickly, and probably falsely, pinned upon Raymond VI of Toulouse, a prominent count in the region who had been accused of heresy on more than one occasion. Finally, the Pope had found his reason for rallying to purge the heretical Cathar movement from Occitania (Strayer 50). ${ }^{3} \mathrm{He}$ as well soon found the means to do so in the social circle of Peter Cantor, a theologian of the twelfth century who had taught a large and influential number of students at Paris, all of whom, by the turn of the 13th century, had gone on to teach as regular masters of theology. Soon after the assassination of de Castelnau, they found themselves appointed to powerful seats of ecclesiastic power. This was more than likely due to the conservative doctrinal views they closely shared with Innocent III, who had himself been a pupil of Peter Cantor (Scott 106).

Cantor's influence had proven crucial in developing the University of Paris out of the small cathedral school it had once been (McLaughlin 178). His teachings promulgated that the Holy Scriptures were the sole foundation of the theological discipline. Theology itself was, to his mind, the "science of all sciences," it was meant to inform all other philosophical disciplines, and not to be impinged upon by them (185). His former students, including the pope, had taken these lessons to heart. There was, however, another sect of theologians at Paris, trained primarily in the arts of logic, that fervently opposed these conservative ideals. It was clear that if the pope had any chance of utilizing the faculty of theology at Paris to his advantage, the dissident theologians and the methodologies from which their beliefs sprouted, needed to be purged.

In 1210 it was revealed to the bishop of Paris, Peter of Nemours, that this sect of logician-theologians at the University of Paris was teaching non-canonical, non-scriptural, beliefs. These beliefs largely stemmed from the teachings of a deceased master named Amalric,

\footnotetext{
${ }^{3}$ For a discussion of the numerous failed papal attempts to entice Philip to join the crusade, see: Lerner, "The Uses of Heterodoxy" 193.
} 
who had lectured primarily in logic before moving to the faculty of theology some years prior (Thijssen 48). To such an extent did the Amalricians' ideas concerning the nature of God and their neoplatonic interpretations of Aristotle disagree with canon (and Cantor), that whispers of heresy came attached with any discussion of them. Something needed to be done about them, but due to the fact that thirteen out of fourteen of these "Amalricians" were members of the clergy, an official synod had to be called to try them for their heretical beliefs, in accordance with canon law (55 and 59). Placed at the head of the investigation as sole judge was the archbishop of Sens, Peter Corbeil, who along with Peter Cantor had taught a younger Innocent III the science of theology, and who had been raised to the powerful position of Archbishop in 1200 by Innocent himself. Joining Corbeil were three other men: Peter of Nemours, the bishop of Paris, who had previously held private correspondence with both the pope and Corbeil in 1205, concerning papal disagreements with King Philip about a potential war in Occitania; Robert de Courson, master of theology and another fellow student of Peter Cantor; and Stephen Langton, yet another master of theology and a close friend of the pope's from their days at school in Paris (Leff 193; Thijssen 44). ${ }^{4}$ The four man tribunal quickly sent an informant back to the Amalricians as a spy in an effort to garner confessions to heretical beliefs. Three months later they received their evidence when the spy returned, after apparently having garnered the trust of the Amalricians and learning of their belief that God could be found in nature (Wakefield and Evans 261). Ecclesiastical justice quickly followed and the written works of Amalric as well as a like-minded master named David Dinant, and all the natural philosophies of Aristotle were all banned, and the heretics sentenced to death (Thijssen 43). As Corbeil wrote:

The body of Master Amalric, who was the leader in the aforesaid depravity, was exhumed from the cemetary and buried in a field. At the same time, it was ordered at Paris that no one should teach from the books on natural philosophy for three years. The writings of Master David and

\footnotetext{
${ }^{4}$ For a discussion on the 1205 letters between Innocent III, Peter Corbeil, and Peter of Nemours, see: Lerner, "Uses of Heterodoxy" 194.
} 
the theological works in the French language were banned forever and burned. And so, by God's grace, the heresy was mowed down just as it was springing up. (Thorndike 262)

Interestingly, ties between Amalric and the French throne prevented the synod from explicitly naming some of the disciples of the heresy, as they had held patronage by the king's son, Louis VIII. These names were ultimately suppressed from the record in an attempt to maintain relations with the French throne (Lerner 190-192). It has been speculated that the executions of the Amalricians was a strategic victory for the papacy in garnering influence over Philip, whom had possibly protected the Amalricians, despite or because of their heresies, as a potential source of political power due to their antihierarchical doctrines concerning the church, and a long-standing French tradition of attempting to limit the excommunicating and judicial powers of the church within French lands (Thorndike 195196). In the end, however, the Amalricians were burned at the stake, and "departed this world in unhappy martyrdom" (Wakefield and Evans 263). The use of the term "martyrdom," is especially telling in this account, seemingly suggesting that though the executed were heretics, their deaths were for the benefit of Christendom. This purge of dissident voices at the university, which came to be known as the condemnation of 1210, marked the first of many acts of censure at the University of Paris (Thijssen 43).

What remains to be seen is how this small and close-knit group of Cantor-inspired and conservatively minded reformers, utilized the situation for papal political gain. For that, we must turn to examine the actions of these elite few theologians in the years immediately following the condemnation of 1210 .

Stephen Langton, having recently been raised from the status of master of theology to the eminent position of archbishop of Canterbury, brought the weight of his newly achieved papal power to the ongoing war between France and England (Scott 107). Langton not only helped to quickly diffuse tension between the English crown and its barons, but soon thereafter drafted and oversaw a peace treaty which put an end to Franco-English hostilities. Hostilities that had, until the peace, been the primary excuse on Philip's tongue as to why he could neither devote the troops, the money, nor the time to the 
Albigensian cause. The archbishop paved the way for France to finally grant its nobility permission to go on crusade (Strayer 52).

As to Robert de Courson, thanks in no small part to his aid in the elimination of the Amalricians and his conservative canonical outlook, he was swiftly raised to the position of papal legate. By 1212 he instituted the incorporation of the faculty of theology at Paris into an independent governing body, separate from the chancellor of the school, bringing the theologians more closely under papal control (Leff 25 and 197). Then, in 1215, Courson penned a series of statutes for the University of Paris precisely dictating academic qualification standards. Among them, the faculty of theology was henceforth limited to a mere eight men, the required number of years one needed to spend in study to become a master of theology was set, and the practice of theology as a master was restricted to those aged 35 and older, thus narrowing potential candidates to those alive during Cantor's time (169). This overhaul of the structure and powers of the faculty of theology was implemented at the behest of the papacy itself, as Courson acknowledged in the opening paragraph of his decree to the university:

Let all know that, since we have had a special mandate from the pope to take effective measures to reform the state of the Parisian scholars for the better, wishing with the counsel of good men to provide for the tranquillity of the scholars in the future, we have decreed and ordained in this wise... (Thorndike 27-28)

Perhaps most telling of the authority lent to Courson's position is the fact that were his decrees disobeyed, the perpetrator was to be instantaneously punished by excommunication (Thorndike 30). Additionally, the statutes took care to officially recognize the purge of 1210 and to legally justify the post-mortem excommunication of Amalric of Bene, an action that had up to that point been canonically unsanctioned (Thijssen 50-51). Later in the same year, de Courson solidified himself as a major political player across Europe when he organized and drafted the Fourth Lateran Council with the pope, in an effort to better codify the papal definition of and appropriate 
punishments for heresy, effectively laying a retroactive foundation for the Albigensian Crusades (Scott 106).

Central to the methods of political maneuvering that the Cantor circle employed were the processes by which heresy was defined and condemned. Indeed, the intellectual and social control adeptly asserted over such matters by the papal powers represented in the Parisian theology faculty held life and death consequences for most of Christendom. The potential for mass death and destruction to those of heretical beliefs had been building for quite some time within in the foundations of the Third Lateran Council, which stated of heretics:

...[W]e decree that they and all who defend and receive them are anathematized, and under penalty of anathema we forbid everyone to give them shelter, to admit them to his land, or to transact business with them... Let their possessions be confiscated and let the princes be allowed to reduce to slavery men of this kind. (Thorndike 169)

For the academic-ecclesiastics of the early thirteenth century the call to war was not too far a stretch from these previous writings of the church, and heresy was centrally defined as a matter of choice between canonical doctrine and everything else, which was rapidly being codified as evil and divinely treacherous error. The chancellor of Oxford, around 1200, stated simply, "Heresy is an opinion chosen by human faculties, contrary to sacred scripture, openly held, and pertinaciously defended. Hairesis in Greek, Choice in Latin" (Peters 190). ${ }^{5}$

In 1215, the Fourth Lateran Council was held, wherein Pope Innocent III and Robert de Courson made new sweeping and ecclesiastically binding changes to the contemporary understanding of heresy. Perhaps most notably, Innocent was the first pope to declare heresy as a crime being equal in weight only to treason, stressing the view that heresy was now to be considered a traitorous act against

${ }^{5}$ Similar anecdotes concerning the will and committal to heresy abound, one notable such is Pelster's Ein Gutachen in which a passage reads "Errare enim possum, hereticus esse non possum; nam primum ad intellectum pertinet, secundum ad voluntatem." For further details, see: McLaughlin, Intellectual Freedom 282. 
what might be thought of as the Christian community (Thijssen 60). The council as well codified that those deemed heretics, being traitors, were now to be held accountable to secular censure and persecuted to the fullest punishments available (Thorndike 174). Amid the council talks, one anonymous eyewitness account recalls discussions of the political concerns surrounding what to do with Raymond of Toulouse in Occitania, concerns over the barons of England, and rumors of the papal management of the crusades (Kuttner 121-122), all of which help to further elucidate just how intrinsically tied politics and the canonical sanctions were. As to how well these new sanctions represented the doctrines of the Cantor group, one need not look much farther than the stipulation that yearly confession to an ecclesiastic official was put into effect a subject that both Courson and Cantor himself had written about at length and endorsed (Wei 239 and 242). The Cantor circle of theologians had by 1215 effectively asserted their intellectual control over doctrine to such an extent as to assert an authority over Catholic society itself (237 and 246).

\section{The Aftermath}

Beginning with the initial citations against Amalric in 1205, the faculty of theology at Paris had been given exclusive rights outside of any secular or ecclesiastical authority to judge "cases of heresy, sortilege, and magic" (Scott 110; Wei 168). Evolving out of Peter of Nemours' initial inquisitorial procedure in 1210 wherein he questioned, judged, and executed heretics by his own devices, and finally being codified within the Fourth Lateran Council, the pope effectively removed the longstanding conciliatory process of caritas (effectively charity) in judging heretics. It was replaced with what could only be defined as a method of potestas, or force (Thorndike 139). After the decretals of Innocent III in 1209 and 1210, and the university condemnations, the delivery of heretical clergy to secular authority for capital punishment was widely accepted (Thijssen 60). Originally, university censure had been used to correct the "false" beliefs held by Christians, not to punish heretical behavior. This was all been changed when Innocent III utilized his trusted confidants within the faculty of theology at Paris to institute a particular idea of heresy as a means of silencing dissenting beliefs for political gain. No 
longer could the educated elite, much less the lower-class populace, be thought of as Christians merely holding heretical beliefs. They were now deemed because of those beliefs to be full-fledged heretics, they were defined by it, traitors to Christendom for all intents and purposes (49).

The pope based the moral rightness of process of inquisitio (the method by which a judge directs any given case and follows the evidence to his own desires) upon biblical allegories of divine process found within the books of Genesis and Luke. Utilizing the teachings of Peter Cantor, who against the processes of ordeal and iudicium dei as means of trial, the pope summarily replaced the long standing legal practices and punishments of the day with an inquisitorial practice and capital punishment (McAuley 474, 468, and 493). This practice was realized instantaneously at the Fourth Lateran Council, when the pope proclaimed of Raymond VI of Toulouse, that he was damnatos de heresi, thus providing not only grounds for the excommunication of a secular lord, but also another post-hoc reasoning for war in Occitania, a war which the King of France was now, thanks largely to the Parisian theologians, fighting (Thorndike 138).

Inquisition as an appropriate form of trial, beginning with the condemnation of 1210 and continuing well into the fourteenth century, was effectively wrought by Pope Innocent III. Theologians, given power by the papacy, were to become the judges, juries, and executioners of heretics. The theologians were quick to capitalize upon this newly found power and sought to establish their ecclesiastical authority appropriately (Wei 184-185). As shown by the purge of the theological faculty at Paris, however, the pope decided precisely who would be one of those select few censures of heretical practice (McLaughlin 264). Thus, the papacy, by 1215 at the latest, through its seizing of control over the Parisian theologians held what can be described as an intellectual monopoly over what knowledge could and could not be deemed to be true. By the end of the Albigensian Crusades less than fifteen years later, the Inquisition was founded, France's boundaries extended all the way to the Mediterranean, and the papacy was at the height of its power. 
Anthós, Vol. VII, Issue 1

\section{Conclusions and Future Research}

In summation, having shown just some of the examples of papal maneuvering at the University of Paris, we can come to understand that the university in the middle ages acted as a real nucleus for change in both the political and religious spheres. So great was its power over knowledge and the interpretation of doctrinal truth, that the state within a state was able to lay the ground for Philip Augustus' entrance into the gory Albigensian Crusades. Even after the establishment of the Dominican order and the inquisition, the faculty of theology at Paris retained the right to judge all local cases of heresy within the jurisdiction of Paris. Having viewed the actions taken by Pope Innocent III, as well as those of the faculty of theology at the University of Paris, juxtaposing their intrigue jockeying and dogma with the realities of political life in the early thirteenth century, we have seen that the Cantor circle of theologians acted directly and purposefully to alter the political landscapes of the Albigensian Crusades. As such, we as historians perhaps need to reevaluate our understanding of formal learning centers in the Middle Ages, and the human actors of which they were composed, in order that we might better recognize them for the cosmopolitan and progressive, albeit malleable, political nuclei that held the capacity to change the fate of even kings and wars.

\section{Works Cited}

Baldwin, John W. Masters, Princes and Merchants: The Social Views of Peter the Chanter \& His Circle. Princeton: Princeton UP, 1970. Print.

Bjork, Robert E., ed. The Oxford Dictionary of the Middle Ages. London: Oxford UP, 2010. Print.

Leff, Gordon. Paris and Oxford Universities in the Thirteenth and Fourteenth Centuries: An Institutional and Intellectual History. New York: Kriege, 1975. Print.

Lerner, Robert E. "The Uses of Heterodoxy: The French Monarchy and Unbelief in the Thirteenth Century." French Historical Studies 4.2 (1965): 189-202. http://www.jstor.org/stable/285843

McAuley, Finbarr. "Canon Law and the End of the Ordeal." Oxford Journal of Legal Studies 26.3 (2006): 473-513. http://dx.doi.org/10.1093/ojls/gql015

McLaughlin, Mary M. Intellectual freedom and Its Limitations in the University of Paris in the Thirteenth and Fourteenth Centuries. New York: Arno, 1977. Print.

Moore, Robert I., ed. The Birth of Popular Heresy. Toronto: U of Toronto P, 1975. Print. 
Peters, Edward, ed. Heresy and Authority in Medieval Europe. Philadelphia: U of Pennsylvania P, 1980. Print.

Scott, John C. The Influence of the Medieval University on the Latin Church and Secular Government Politics: From the Later Middle Ages to Early Modern Times. New York: Mellen Research UP, 1992. Print.

Strayer, Joseph R. The Albigensian Crusades. New York: Dial, 1992. Print.

Thijssen, J. M. M. H. "Master Amalric and the Amalricians: Inquisitorial Procedure and the Suppression of Heresy at the University of Paris." Speculum 71.1 (1996): 43-65. http://dx.doi.org/10.2307/2865200

Thorndike, Lynn. University Records and Life in the Middle Ages. New York: Norton, 1975. Print.

Wakefield, Walter L. Heresy, Crusade and Inquisition in Southern France, 11001250. Berkeley: U of California P, 1974. Print.

Wakefield, Walter L., and Austin Patterson Evans, eds. Heresies of the High Middle Ages. New York: Columbia UP, 1991. Print.

Wei, Ian P. Intellectual Culture in Medieval Paris: Theologians and the University, 1100-1330. New York: Cambridge UP, 2012. Print. 